\title{
Jaké to je vstupovat do světa?
}

\author{
Tomáš Korda \\ Filozofická fakulta \\ Univerzita Karlova v Praze \\ Nám. Jana Palacha 2, 11638 Praha 1 \\ t.korda@seznam.cz
}

\begin{abstract}
Předkládaná stat’ je obsáhlejší recenzí knihy Terezy Matějčkové Hegelova fenomenologie světa. Zdůrazňuji, že v její interpretaci hraje klíčovou roli pojem vzdělání. Nikoli toliko ve smyslu akumulace vědění, ale ve smyslu zbavování se vědění, které již neodpovídá skutečnosti. V mém čtení pak skrze opakované osvobozování se od starého vědění vstupuje vědomí do světa, nechává za sebou starý „,světový řád“ a učí se současně žít na výši přítomnosti. Svět a (každodenní) přítomnost je to, čemu podle Matějčkové učí Hegelova Fenomenologie ducha dostát. Nejen vědomí, ale i čtenář má dostát světu, nebot je rovněž vědomím. Moje základní výhrada či spíše podnět k rozvedení spočívá v tom, že aby tohoto cíle Fenomenologie dosáhla, měl by její interpret vzít v potaz dějiny dvacátého století a ukázat, jak se na nich duch vzdělal a pozvedl je $\mathrm{k}$ dějinám ducha. $\mathrm{V}$ opačném případě čtenář bude stále rámovat př́tomnost pojmy převzatými z minulosti a nebude skutečně moderní.
\end{abstract}

Klíčová slova: vzdělávání, přítomnost, svět, práce, postmetafyzické čtení Hegela, Matějčková

Svou recenzi sborníku Místo fenomenologie ducha v současném myšlení zakončuje Tereza Matějčková slovy, že v něm postrádá jednotící ohled na klíčovou vlastnost ducha, kterou je vzdělávání se. Na místo zřetelného „podání dějin vzdělávajícího se ducha“ získává čtenář spíše „pouze velmi matnýobraz ofenomenologiijako cestě, na kterése specifickéstrukturyvě-

1 Narážka na název článku Thomase Nagela Jaké to je být netopýrem? (Nagel 1974). 
domí postupně diferencují v rozvažování, sebevědomí, rozum a ducha.“" Jak tedy Matějčková chápe dějiny vzdělávajícího se ducha? Svou knihou Hegelova fenomenologie světa ${ }^{3}$ na tuto otázku odpovídá.

Aby dějiny vzdělávajícího se ducha držely pohromadě, autorka se ani nemohla vzdát základního Hegelova nároku uchopit celek a vidět jednotlivé pasáže Hegelovy Fenomenologie v souvislosti s celkem tohoto díla. Jinak by hrozilo, že výklad jednoho oddílu nebude kompatibilní $\mathrm{s}$ výkladem jiného, celek se jednoduše rozpadne a $\mathrm{z}$ knihy zbydou kapitoly. Čili vidět konkrétní očima těch nejširších souvislostí celého díla je sice nárok velkolepý, leč současně nutný.

Zde by snad Matějčková mohla svi̊j podnik ospravedlnit poněkud silněji než jen svým rozhodnutím. Kromě uvedené nekompatibility výkladů jednotlivých kapitol se může také stát, že když se badatel pustí do „skromnějšího“ vyložení, třeba jen jedné kapitoly Fenomenologie, vystavuje čtenáře napospas zobecňování, tedy tomu, že celek bude chápat z části a nikoli část z celku. Alexander Kojève např́ílad učinil z pojmů žádostivosti (Begierde) a uznání, respektive žádostivosti po uznání, těžiště celého Hegelova díla, a nakonec i lidských dějin, přestože ve Fenomenologii má žádostivost přesně vymezené místo. Dokud však čtenář nedostane odpověd’ na otázku, o čem celé dílo jest, nemůže očima celku číst jednotlivé kapitoly a nelze mu proto vyčítat, že zevšeobecňuje. Jestliže se má kontaminace celku některou z částí vyvarovat, musí vědět, jakým pojmem celku má číst jednotlivé úseky Fenomenologie.

Interpretačním klíčem $\mathrm{k}$ otevření všech kapitol slouží Matějčkové pojem vzdělávání (Bildung). Leč jeho „smůlou“ je, že i když se z němčiny (do)přeloží jako utváření a formování, nadále je spoután s představou, že vzdělávání znamená (kvantitativní) nárůst vědění. Vzdělaný ví více než nevzdělaný. Na druhou stranu tato představa o vzdělávání však není tak úplně nepravdivá, ale „jen“ omezená či jednostranná. Hegel, než aby s touto zažitou představou zápolil, ji spíše rozvíjí, jak je jeho dobrým zvykem, a to až do bodu jejího převrácení či spíše podvrácení, v němž se vědomí vzdělává a získává vědění tím, že poznává omezenost svého dosavadního vědění (o světě).

2 Matějčková (2011).

3 Matějčková (2020a). Odkazy na recenzovanou knihu budu uvádět přímo v textu v závorkách. 
Pro Matějčkovou tedy klíčem k Fenomenologii není jednoduše vzdělávání, ale spíše vzdělávání jakožto opakované zbavování se ${ }^{4}$ vědění ve smyslu očištování se od představ a názorů, provizorních „plánků“ ${ }^{5}$ a „mapek“, které si člověk o světě dělá a které si na jedné straně dělat musí, aby se ve světě vůbec orientoval a aby poskytovaly jeho jednání ve světě smysl, avšak na straně druhé se musí člověk vzdělávat a učit se jich zbavovat, zříkat se jich a podstupovat jejich ztrátu, jakmile začnou „navádět“ špatně, neodpovídat skutečnosti a, na místo orientace ve světě, člověka ze sdíleného světa spíše stahují, uzavírají ho před ním a vůbec ho nutí svět ponižovat a přezírat (s. 18). Vzdělání v tomto smyslu znamená akumulaci vědění, představ a názorů, kterých jsem se zbavil, protože jinak bych jimi svět násilně přemáhal a na úkor světa bych přetěžoval i svou subjektivitu. Ta pak, mohl by dodat Axel Honneth, snadno trpí neurčitostí a podléhá různým patologiím. ${ }^{6}$

Vzdělávání tak vystupuje jako limitace vědění, omezení jeho platnosti, např́klad omezení platnosti oněch pojmů žádostivosti a uznání. Avšak Hegel uděluje této limitaci vědění ontologický rozměr, který je částečně předznamenán již v Kantově kategorii limitace jakožto syntézy reality a negace. Vzdělávání nelimituje jen vědění, ale i svět, respektive jeho trvání, protože „konstatované vědění bylo bytostně věděním“7 světa, jeho ohraničujícím horizontem, který svět rámoval a tím ho současně konstituoval. Rád bych tak vzdal hold krásné větě, kterou nacházíme v jedné ze závěrečných kapitol recenzované knihy, že např́č svým dílem učí Hegel „obětovat dnešek pro zítřek“ (s. 335).

Tomuto obětování rozumím tak, že vzdělávání učí zadržovat prodlužování dneška do zítřka. Nejde zde o bezprostřední zastavování nynější společenské praxe, nýbrž o cosi původnějšího, o zabrzdění a změnu našeho vědění o světě, jež ho rámuje a z něhož vědomí světu rozumí a vykládá ho. Jako limitování vědění lze číst i Hegelův pojem státu, který jako nové vědění vzniká limitací (působení) vědění či pojmu

\footnotetext{
4 Německé Entäußerung Patočka překládá jako zbavování se, respektive sebezbavování se. Zvnějšnění se sice nabízí jako přesnější překlad, ze kterého se ale podle mého soudu vytrácí existenciální rozměr.

5 Matějčková (2020b).

6 Honneth (2001).

7 Hegel (1960, s. 102).
} 
občanské společnosti. Pojem státu tak zabraňuje tomu, abychom „očima“ pojmu občanské společnosti („zdola“) analyzovali stát a již kognitivně ho např́klad degradovali na stát kapitalistický.

Svou ochotou obětovat dnešek pro zítřek vyvrací absolutní vědění vůči němu tradované podežrení mnoha nejen hegelovských badatelů, že $\mathrm{v}$ úsilí o svou absolutnost se vymaňuje z času a povznáší se nad něj. „Nikoli navzdory časovému plynutí, ale spolu s ním, resp. v něm se vědomí završuje“ (s. 334). Obětováním dneška pro zítřek nechává absolutní vědění čas působit, nechává ho, aby jako svičku sfouknul zchřadlý svět, a to tím, že nový den jakožto nový jev pozvedá na prubířský kámen včerejšího vědění. Je-li netrpělivost známkou unáhleného prosazování vlastního vědění na úkor toho nového, co přináší plynutí času, pak Fenomenologie učí také trpělivosti, učí, že nový den, který má moc vyvrátit včerejší vědění, už dávno přišel.

Obětování se chápu komplementárně s celou řadou pojmů jako sebezbavování se (Entäußerung) ${ }^{8}$, odvnitřnění se k bytí (sich zum Sein zu entäußern) a převrácení se ve skutečnost, ${ }^{9}$ odpuštění jako zřeknutí se sebe sama, ${ }^{10}$ učinění se věcí, snésti tak bytí1 ${ }^{11}$ a vyzápolit své bytí pro sebe ven jakožto věc. ${ }^{12}$ Takovéto zpředmětňování se ve smyslu „vyprazdňování“ vlastního nitra od různých předsudků má ten význam, že si vědomí tímto zvnějšňováním razí cestu do světa (s. 20). Doslova se do světa propadá, do jeho stále podstatnějších a trvalejších struktur, $\mathrm{k}$ jeho základům, původu (srov. s. 48). Učí se chodit po hlavě. ${ }^{13}$ Vědomí do světa proniká. Ale ne tak, že nechává svět svým věděním prosívat, protože pak by síto alias vědění zůstalo nezměněné, vědomí by se nijak nevzdělalo, nijak nevyprázdnilo a získalo by jen „nové pohledy starými dírami““. ${ }^{14}$ Vědomí se proto světem nechává vzdělat, jen když mění a vydává ze sebe vědění, kterým si svět prosívalo a představovalo, či přesněji, kterým si svět před

8 Tamtéž, např. s. 238, 239, 315 a 318.

9 Tamtéž, s. 413.

10 Tamtéž, s. 414.

11 Tamtéž, s. 407.

12 Tamtéž, s. 239. „Das unglückliche Selbstbewusstsein entäußerte sich seiner Selbständigkeit und rang sein Fürsichsein zum Dinge heraus“" (Hegel 1986, s. 260).

13 Hegel (1960, s. 65).

14 Lichtenberg (2004, s. 61). 
sebe stavělo a jímž se i od světa distancovalo. Když vědomí změní toto své vědění, podlamuje se mu pod ním tento jeho odstup, kterým si od světa udržovalo bezpečnou vzdálenost a současně ho drželo na uzdě.

Úvodem Matějčková zdůrazňuje, že vědomí původně neupadá ve světě, ale v sobě samém (s. 37). Na což lze navázat Hegelovou větou, že vědomí sice může úzkostlivě ,zajisté couvati před pravdou a snažiti se uchovati to, čeho ztráta hrozí. Nemůže však dojíti klidu, chce-li se zastaviti v bezmyšlenkovité nečinnosti - myšlenka zkalí bezmyšlenkovitost“. ${ }^{15}$ Proto podle Matějčkové vědomí nezbývá než vstoupit do světa, přehodnotit svá stávající hodnocení (s. 37). Toto přehodnocení coby změna vědění je pro Hegela bytostně reflexí, avšak reflexí, ke které se vědomí svobodně uchyluje, až když už nemá na výběr a nezbývá mu než vstoupit do světa. Tato reflexe stojí až na samém konci a je svým zpo̊sobem tím posledním, co zbývá, jestliže platí, že světu nemáme vnucovat naše (jistě dobře míněné) rady, představy a hodnocení, a proto ho máme chápat jako završený či hotový (s. 284). Jen tak se vyvarujeme toho, abychom svět „komandovali“. Avšak coby hotový je nám svět současně zcela cizí, tudíž vstupovat do něho a nechat si jím zkazit své přesvědčení je tím posledním, po čem bychom toužili. V této situaci zbývá jen ona reflexe, která včlení vědomí do světa tím, že mu ukáže, že navzdory jeho přesvědčení se ve světě - jemu tak odpudivém a cizím - již dávno nachází a participuje na něm. Výstižně tuto Hegelovu reflexi znázorňuje jeden vtip stvrzující slova Vladislava Vančury, že humor není smát se, ale lépe vědět. Ke svému lůžku si hospitalizovaný přivolá doktora, aby mu vysvětlil ten nesnesitelný křik ostatních pacientů kolem. Doktor ho poprosí o schovívavost. Nemocní se totiž právě dozvěděli, že umírají. Proto tak naříkají. Přesto se náš pacient s touto odpovědí nespokojil a pohotově se zeptal, zdali by právě proto nemohli být převezeni na nějaké detašované oddělení pro umírající. Ale milostivý pane, odvětí doktor pohotově, právě tam už se nacházejí. Touto reflexí se náš pacient včlenil do nesnesitelného světa umírajících, osvojil si ho, aniž by se v něm rozpustil a ztratil pocit svobody. A svět? Ten se mu rázem proměnil a ztratil svou cizost a nesnesitelnost, aniž by bylo zapotřebí jej intelektuálně „zkonzumovat“ a takzvaně přetavit

15 Hegel (1960, s. 99). 
substanci v subjekt. Pacient se „jen“ smířil se světem, s jeho dokonalostí a završením v právě panujícím statutu quo. Už nechce svět od sebe odsouvat a podrobovat ho tak své vůli. Zjištuje, že odsunutý již je a on s ním. Že „absolutno“ je u něj.

Ač vyhroceně ukazuje snad dobře tento vtip na to, jak máme chápat, když podle Matějčkové Hegel učí brát svět jako již dokončený. Vycházeje z tohoto př́ikladu, domnívám se, nestačí se spolu s autorkou postavit za slova Milana Sobotky, že Hegel je v nejlepším smyslu advokátem přítomnosti (s. 22). Nebot’ co znamená ono „v nejlepším slova smyslu“? Zvláště liberálně-marxistické kruhy, které odnepaměti podezřívají Hegela z komfortního konformismu, nejspíše neuspokojí, když se dozví, že Hegel je sice advokátem přítomnosti, ale v nejlepším slova smyslu. Uvedený vtip však naznačuje, jak nekomfortní i nekonformní je považovat svět za hotový a být advokátem přítomnosti v tom nejlepším slova smyslu.

Pokud se vrátíme $\mathrm{k}$ výchozí premise knihy, že vědomí původně neupadá ve světě, ale v sobě samém, a činí tak navzdory sdílenému světu, který je již u něho a chce být u něho, potom se pojmy světa a absolutna Matějčkové významově přibližují, a to do té míry, že se čtenář může ptát, v čem tkví jejich vzájemný rozdíl. Obojí chce být u nás a je již u nás, nám navzdory, nakolik ulpíváme na sobě samých a nechceme přehodnotit naše zavedená hodnocení.

Blízkost obou pojmů vybízí k otázce, zda slovy Marxe Matějčková neobrátila Hegela z hlavy na nohy, leč nemarxistickým způsobem: těžko srozumitelný a s metafyzikou spárovaný pojem absolutna „jen“ nahradila daleko svět-štějším pojmem světa. Pak by skutečně platilo, že vjednoduchosti je i krása. V posledním důsledku by dokonce mohlo platit i to, že tento její krok za sebou nechává celý takzvaný ne-metafyzický směr hegelovského bádání. ${ }^{16}$ Stačí si za absolutno, které chce být u nás, jako Ježíš Kristus, dosadit svět a „rázem“ celá Fenomenologie vypadá daleko průhledněji, či - chcete-li - ne-metafyzicky.

Jakmile vědomí dosáhne absolutního vědění, má se znovu nechat bezprostředností vychovat až k dospělosti (s. 38). ${ }^{17}$ Takové je absolutní

16 K této otázce se ale vrátím v samotném závěru.

17 Srovnej Hegel (1960, s. 487). 
stanovisko ve světě (s. 328). Jak ale takovou výchovu máme chápat? V interpretaci Matějčkové tak, že „výchova“ bezprostředností je cesta, která sama je již cílem, a absolutní vědění je pak stvrzením této cesty a její pomyslnou tečkou, která stejně jako tečka za větou čtenáře upozorňuje, aby na moment přestal hltat další text a zamyslel se nad tím, cože to vlastně přečetl. „Nejpozději nyní by čtenář měl vědět, cože to je absolutní vědění“ (s. 328). Pokud ani ted' po přečtení celé Fenomenologie čtenář nedospěl k závěru, že všechno podstatné již zaznělo, může začít číst celou knihu znovu od začátku.

Nechat se bezprostředností vychovat až k dospělosti však skýtá podle mne jednu potíž, která tkví v tom, na co v jiné souvislosti autorka sama upozorňuje, že Hegel píše Fenomenologï na pozadí světa roku 1806 (s. 27). Hegel jakožto autor a vědomí vychované bezprostředností natolik, že je schopen vyložit dějiny vzdělávajícího se ducha (tj. napsat svou Fenomenologii), nemůže překročit svou dobu, tudíž čtenáře, který „má zkušenost vědomí převzít“, propouští svou Fenomenologií na svobodu do bezprostřednosti světa své doby.

Opakovaná četba Fenomenologie naučí sice čtenáře obecným způsobům, jak svět poznávat, a potažmo i jak se ve světě a ke světu chovat, jak ze svých hodnocení slevovat a nad jeho banální každodennost se nepovyšovat. Vždyt „heroické“ vyvýšení se nad průměrnost a bídu světa by totiž bylo nejen protestem proti ní, ale i jejím výrazem, máme-li se vyjádřit Marxovými slovy na adresu náboženství.

Na obecné zásadě nechat se světem vychovávat tedy netřeba nic měnit, protože platí dnes jako i na pozadí světa Hegelovy doby. Jenže čtenář narazí na problém, vyjde-li dnes po přečtení Fenomenologie testovat a ověřovat vědění, které mu z ní vyplynulo. „Očistná kúra“ čtení Fenomenologie ho sice zbaví mnoha (předsudečného) vědění, které měl, než začal číst, ale nezbaví ho vědění, jehož ho zbavit nemůže a které si udělal o dějinách, jež se udály po Hegelovi. Čtenář neví, jak se vzdělávající se duch na nejnovějších dějinách vzdělal, jakou zkušenost na nich učinil, jakého vědění se na těchto dějinách musel vzdát. Jen pak by mohl jeho zkušenost převzít a zhostit se jí (s. 337).

Narážím na to, zdali autorkou často citovaná výzva nechat se bezprostředností opětovně vychovat až k dospělosti, nemá - budeme-li kon- 
sekventní - nakonec vyústit v sepsání revidované verze Fenomenologie, která teprve dosvědčí, že duch se po Hegelově smrti vzdělávat nepřestal. Musela by obsáhnout i ty nejnovější dějiny ducha a ukázat, jak se duch právě na nich (do)vzdělal. Až jen takováto aktualizovaná verze by čtenáře vskutku vyzvala, aby šel a díval se aosobně si na dnešní bezprostřednosti ověřoval, že vědění včerejška dnes už neplatí, že včerejší hodnoty již špatně hodnotí a že již včera uplynul ten nejvyšší čas se jich zbavit.

Kniha Terezy Matějčkové přesto vykračuje směrem $\mathrm{k}$ nejnovějším dějinám. Je plná zdařilých dialogů, v nichž Hegel daleko současnějším myslitelům nejen úspěšně sekunduje, ale dokonce odhaluje přednosti, jaké plynou z toho, že pojmy života, smrti, práce, vzdělání, světa a celé řady dalších klíčových termínů zpracoval právě tak a ne jinak. Je více než čtenářsky přivětivé, že autorka nepřepadává těmito dialogy čtenáře ze zálohy. Dialogy se spíše samy nabízejí při rozboru jednotlivých zastávek coby podob světa a jim odpovídajícím podobám vědomí. Na úrovni poznámky pod čarou bych jen zmínil, že pod plasticky vykreslenými podobami světa zaniká přechod mezi nimi. Čtenář si tak dobře dokáže představit, čím vším si vědomí prochází, ale částečně na úkor toho, že přesně neví, jak a proč jedna podoba světa přešla v druhou.

Dialogy se současnějšími filosofy v rámci jednotlivých podob světa dávají na jedné straně čtenáři vědět, jak se k problému, kterému vědomí právě čelí, stavěli jiní myslitelé, jak řešili daný problém a koncipovali ten či onen pojem. Odtud je ale zřejmé, že se tyto dialogy pohybují na rovině intelektuální, na rovině dějin pojmů. Zdárně sice aktualizují Hegela coby filosofa, ale ještě „neaktualizuji“ či nevzdělávají samotného ducha, který neví, jak Hegelovy pojmy, jež mají stát na výši doby, interagují se „skutečnými“ dějinami či jak z těchto dějin vyplývají jakožto reflexe na ně. Vazba Hegelova myšlení na Francouzskou revoluci je známa a ve Fenomenologii Hegel vynakládá nemalou práci, aby ukázal, jak „projekt“ osvícenství kulminuje a limituje se $\mathrm{v}$ revolučním teroru. $\mathrm{K}$ čemu ale navázat Hegelovo myšlení dnes? Domnívám se, že vzít po Hegelově vzoru v potaz „skutečné“ dějiny bude nutné, pokud běží o aktualizaci jeho myšlení.

Protože Francouzská revoluce rozpůlila tehdejší Evropu na revoluční Francii a monarchistický zbytek Evropy, čistě hrubou asociací bych 
navrhoval vztáhnout se k rozdvojení světa vrcholícího za studené války. Podezřele nápadný je pak zvláště fakt, jak bylo toto rozdvojení různými, a navíc vzájemně soupeřícími intelektuálními projekty ponižováno. Jednak tu máme teorie totalitarismu, které podobně jako stalinismus kontaminují jednu ze stran studenoválečného rozdělení nacismem, respektive fašismem, čímž zaniká rovnocennost obou stran a tím i sama rozdvojenost „projektu“ moderny. Dále byl Západ i Východ podřazován pod jeden metafyzický princip (neschopný myslet bytnost techniky), čímž je rozpolcenost moderny opět setřena. Totéž pak platí pro nahlížení obou režimů pod zorným úhlem jedné instrumentální racionality.

Na tomto zahlazování rozpůlení světa, na němž se sjednocují vůči sobě jinak nepřátelské filosofické projekty, mohla autorka podle mého názoru dokumentovat, vůči jakému způsobu dělání filosofie se spolu s Hegelem jasně vymezuje. Jak stojí na přebalu, „filozofické tázání, jež se ze své podstaty nachází na hranici banality a hloubky, nás nemá vést mimo průměrnost běžného života, nýbrž učí dostát každodennosti“. Filosofie ale odvádí od každodennosti, když zahlazuje ono rozpůlení světa, jehož byl i ten nejprůměrnější život svědkem. Kdyby autorka povýšila svět přetatý vedví na prubířský kámen každé další filosofie (nejen v duchu Hegelova vyzdvihnutí významu Francouzské revoluce, ale poplatně i jeho tezi, že světové dějiny jsou světovým soudem), našla by v těchto nejnovějších dějinách světa objektivní, na Hegelovi nezávislé měřítko a snad ještě zajištěnější odstup od Hegela, než který spatřuje v pojmu světa. ${ }^{18}$ Toto měřítko by posoudilo, nakolik a zdali na rozdíl od jiných filosofií, jež rozdvojení světa nivelizují, by se Hegel něčeho takového nedopouštěl a dal tak Matějčkové za pravdu v tom, že nevyzývá čtenáře k paušalizujícím „přeletům nad pouhým jevovým světem, ale spíše podniká hlubinné vrty, které osvětlují, proč jsou věci, tak jak jsou“ (s. 31).

Věta z Fenomenologie, že „duch je tím větší, čím větší je protiklad, z něhož se k sobě vrací“, ${ }^{19}$ nasvědčuje tomu, že Hegelova filosofie by snad obstála ve zkoušce dvacátého století, jež svět rozetnulo ve dví. Duch totiž není silný toliko proto, že je Hegelovým géniem teoreticky vybaven

18 Matějčková (2020b).

19 Hegel (1960, s. 238). 
tak dobře, že dopředu zvládne ustát i ten nejhlubší rozdíl, ale protože je jen do té míry duchem, nakolik se i z té největší rozervanosti dokáže pozvednout, jako fénix z popela.

Kapitola „Od práce k teroru?“ dobře ilustruje krok Matějčkové k nejnovějším dějinám, ale současně i její setrvávání na rovině pojmů a dějin filosofie. Matějčková přesvědčivě zachraňuje Hegelovo pojetí práce před totalitarismy, které ve dvacátém století učinily z práce jeden ze svých stěžejních pojmů. Např́íklad Hannah Arendtová, kterou Matějčková dává do kontrapunktu k Hegelovi, se této totalizace či vítězného tažení práce zalekla a pojem práce zvnějšku ohraničila jinými pojmy: zhotovováním a jednáním (s. 287). Na rozdíl od Arendtové však Matějčková před totalitarismy necouvá. Totalizaci práce nevnímá jako teoretickou předzvěst totalitární praxe, protože jakkoli „Hegelovi můžeme vytýkat redukci nejrozmanitějších lidských aktivit na práci“, tato výhrada ztrácí svi̊j kritický osten, jestliže Hegelovi nemůžeme „vytýkat redukci práce na užitek“ (s. 287). Práce u Hegela nemůže zahlazovat pluralitu světa a nivelizovat ho, protože „překračuje intence pracujícího“ (s. 287). Pracující není „pánem“ své práce, a proto si ani nemůže prací svět podrobovat. A protože práce překračuje jeho intence, může se na ní i vzdělat a změnit perspektivu, jakou nahlíží na svět.

Jakkoli tyto polemiky zdařile polemizují s koncepcemi jiných myslitelů a intervenují do dvacátého století, čtenář se přesto může ptát, proč když je Hegel filosofem tohoto světa, proč nejnovější dějiny světa nezaujímají ústřednější úlohu, když právě na nich by si čtenář mohl bezprostředně ověřit, zdali Hegel skutečně je filosofem nejen jeho ale i této př́tomnosti. Čtenáři by tak autorka dala možnost, aby spolu s ní vystoupal až k vrcholkům té dnešní doby. Postrádaje však „žebřík“ k té nynější skutečnosti čtenář nadále zůstává vězet $\mathrm{v}$ minulosti a rámuje tuto př́ítomnost starými (např́íklad studenoválečnými) pojmy. Zkrátka autorka ho přesvědčuje, že chce-li dostát př́tomnosti, v Hegelovi najde robustní filosofickou oporu. Leč po přečtení Hegelovy fenomenologie světa zůstává čtenář nadále neschopen obětovat dnešek pro zítřek, přestože z četby ví, že tak má učinit.

Předkládaná výhrada ohledně absence nejnovějšího historického materiálu je vůči recenzované knize samozřejmě vnějšśi, ale snad jen do 
té míry, pokud autorčiny přesahy do současnějšího myšlení nebudeme chápat jen jako polemické intervence, ale podstatněji jako snahu zpř́tomnit či aktualizovat ducha, který se chce (fenomenologicky) na svých dějinách dál vzdělávat, chce být u nás.

Z hlediska tohoto nároku zůstává stát počin Matějčkové na půli cesty. Hegelovu Fenomenologii sice ještě zcela neaktualizuje, ale současně ji ani již jen nepřipomíná. Autorka totiž svým výkladem Fenomenologie implicitně překonává etablovaný akademický spor, zda číst Hegela spíše metafyzicky, či ne-metafyzicky. At’ už Hegel pod svou spekulativní metafyzikou myslel cokoli, jasné je, že současná doba tak nemyslí, čímž vzniká potíž a následně otázka, zda si z Hegela odnést alespoň něco, totiž to, čemu ještě rozumíme a co je tedy v Hegelovi ne-metafyzické, anebo číst Hegela se vší metafyzickou „bagáží. Cena za aktualizaci „kusu“ Hegela však může být i taková, že v něm Hegela už nerozpoznáme. ${ }^{20}$ Takový podnik může $\mathrm{v}$ krajním případě připomínat vivisekci: dobře míněná analýza, která v Croceho duchu chce oddělit to, co je v Hegelovi živé a co již mrtvé, nakonec zabije život sám. Výsledný Hegel pak vypadá stejně neživě jako ten metafyzický, který byl zkraje odmítnut právě pro své mrtvolné vzezření. ${ }^{21}$

Tento začarovaný kruh Matějčková šikovně, byt’ nenápadně roztíná. Jak bylo naznačeno výše, pojem absolutna, resp. ducha nahrazuje pojmem světa. Ukazuje tím Hegela v ne-metafyzickém světle jako myslitele vezdejšího světa, avšak aby tohoto cíle dosáhla, zaměstnává „všechnu“Hegelovujinak těžko srozumitelnou nábožensko-metafyzickou terminologii. Metafyzično zde není cílem, ke kterému bychom se měli

20 Horstmann (2006). Tuto svou výhradu ve svém článku směřuje Horstmann především k anglosaským interpretům (Pippin, Pinkard). Dále ji lze ale upřesnit na případu Axela Honnetha. Oproti zmíněným Anglosasům Honneth nečte vyzrálé Hegelovo dílo ne-metafyzicky, nýbrž ho nečte vůbec v tom smyslu, že se ve své knize Boj o uznání zcela programově v duchu ne-metafyzické četby vrací před Fenomenologii ducha, která již vychází z metafyzických premis a pojem uznání je v ní zatížen metafyzikou sebepoznání ducha, a taková metafyzika je slovy Honnetha těžko smiřitelná se současným myšlením (Honneth 1995, s. 67).

21 Na problém vivisekce Hegel naráží v samotném závěru kapitoly Fysiognomie a frenologie: „Mozková vlákna, uvažovaná jako bytí ducha, jsou již myšlená skutečnost, skutečnost jen hypotetická - nikoli skutečné jsoucno, nikoli skutečnost cítěná, viděná, pravdivá; jsou-li dána, vidíme-li je, jsou to neživé věci a neplatí pak již za bytí ducha.“ (Hegel 1960, s. 240-241) Analogicky k tomu vyvozuji: ne-metafyzický Hegel je jen myšlená skutečnost, skutečnost jen hypotetická. Je-li ne-metafyzický Hegel dán, vidíme-li ho, čteme-li ho, je neživou věcí a neplatí již za bytí Hegela. 
propracovat, nýbrž prostředkem, jehož spotřebováním (či vykrácením) vstupujeme do světa a učíme se $\mathrm{v}$ něm žít. Nenapadá mne jediný pojem, který by Matějčková tiše přecházela, protože by ho nedokázala produktivně upotřebit pro svou interpretaci. Pojmy smíření a překonání, učinění se věcí a znicotnění, subjektivace substance a převrácení, odpuštění a obětování, zkrátka to náboženské a metafyzické v Hegelovi Matějčková spaluje jako benzín k odhalení ne-metafyzického, či př́ímo existenciálního ${ }^{22}$ Hegela.

Tímto Matějčková roztíná spor o to,jak Hegela číst: s ne-metafyzickým směrem sdílí zájem o to, aby Hegel promlouval k dnešnímu člověku, a neuzavírá Hegela do jeho doby. Avšak právě proto není ochotna na rozdíl od představitelů tohoto směru obětovat, přecházet či rozmělňovat to metafyzické v Hegelovi. Svou neochotou Hegela osekat od metafyzična stojí na straně metafyzické četby, leč na rozdíl od Horstmanna, kterého zde vybírám jako čelního představitele tohoto směru, neohraničuje Hegela jeho dobou, nečiní z něj neživý předmět dějin filosofie, na který se díváme, jako když se díváme na gotické katedrály. ${ }^{23}$ Matějčková se nevzdává ne-metafyzického nároku podat Hegela tak, že chce být v tomto světě u nás a svou filosofií chce učit žít. Zkrátka na rozdíl od obou proudů bádání, čímž je v hegelovském smyslu překonává, Matějčková nerespektuje (nakonec metafyzickou) rozluku na onen svět a tento svět, svět doby metafyzické a svět dnešní doby ne-metafyzické, svět Hegelovy doby a svět naší doby, svět vědy a svět života. Toto rozdvojení na světy dva oba proudy bádání sdílí a sdílet musí, protože představuje samu podmínku jejich možnosti, jejich vzájemného sporu.

Ruku v ruce s tím, jak Matějčková jaksi mimochodem nechává tento akademický spor za sebou, můžeme rozumět jejímu rozhodnutí nečíst Fenomenologii jako úvod do vědy (s. 38). Toto rozhodnutí bych si však dovolil problematizovat následující citací jednoho výňatku z Hegelových přednášek z let 1801 až 1802:

22 Matějčková (2020).

23 Srovnej Horstmann (1999). 
„Pokud jde o to, co je na potřebě filosofie obecné, tak to se chceme pokusit objasnit formou odpovědi na otázku týkající se vztahu filosofie k životu, která je totožná s otázkou, nakolik je filosofie praktická. Nebot’ opravdová potřeba filosofie přece asi nespočívá v ničem jiném, než v tom, učit se od ní a skrze ni žít. Ona sama může být sice také považována za uvedení do věd, za způsob vnějšího utváření rozumu, ale my od tohoto podřadného účelu chceme prozatím odhlédnout a spíše se domníváme, že se potřebě filosofie pouze špatně rozumí, věří-li se, že má jen tento účel, kterého je jistě dosaženo také studiem filosofie, a že ve skutečnosti má před sebou daleko obsáhlejší a vznešenější cíl.“24

Na jedné straně je uvedení do věd coby způsob vnějšího utváření rozumu označeno za podřadnější cíl, což by nahrávalo rozhodnutí autorky číst Fenomenologii spíše tak, že učí žít. Na druhou stranu obojí, jak utváření rozumu, tak učení se žít, se nijak nevylučuje a spíše jde o dva pohledy na jednu věc a oba patří k sobě. Nevidím tudíž důvod se rozhodovat pro jeden či druhý způsob nahlížení na Fenomenologii. Spíše stojí za ukázání, jak oba náhledy fungují komplementárně, což lze vyčíst nejen z výše uvedené citace, ale z rámce celkového procesu vzdělávání jakožto zbavování se a očištování se od vědění, názorů a předsudků a obecně přehodnocování vlastních hodnocení. Není třeba se rozhodovat mezi životem a úvodem do vědy, nebot’ spíše platí, chceš-li dělat vědu, nauč se žít.

24 „Was das allgemeine des Bedürfnisses der Philosophie betrifft, so wollen wir es in der Form einer Antwort auf die Frage, welche Beziehung hat die Philosophie aufs Leben? klar zu machen suchen, eine Frage, die eins ist mit der: inwiefern ist die Philosophie praktisch? Denn das wahre Bedürfniß der Philosophie geht doch wohl auf nichts anders als darauf, von ihr und durch ihr leben zu lernen. Sie selbst kann auch wohl auch als Einleitung in Wissensschafften, als eine Art von aüsserer Verstandesbildung angesehen werden, aber wir wollen diesen untergeordneten Zwek einstweilen aus der Augen lassen, oder vielmehr glauben, daß das Bedürfniß der Philosophie, wenn es nur diesen Zwek zu haben glaubt, der allerdings auch durchs Studium der Philosophie erreicht wird, sich nur misversteht, und im Grunde ein weitumfassenderes und würdigeres Ziel vor sich hat." (Hegel 1998, s. 261). 


\section{Literatura}

Hegel, G. W. F. (1960): Fenomenologie ducha. Nakladatelství Československé akademie věd, Praha.

Hegel, G. W. F. (1986): „Phänomenologie des Geistes.“ In Hegel, G. W. F.: Werke in 20 Bänden mit Registerband, eds. E. Moldenhauer \& K. M. Michel. Suhrkamp, Frankfurt am Main, 1986, svazek 3.

Hegel, G. W. F. (1998): „Schriften und Entwürfe (1799-1808).“ In Hegel, G.W.F.: Gesammelte Werke. Felix Meiner 1968ff, Hamburg, 1998, svazek 5 .

Honneth, A. (1995): The Struggle for Recognition. Polity Press, Cambridge.

Honneth, A. (2001): Leiden an Unbestimmtheit: Eine Reaktualisierung der Hegelschen Rechtsphilosophie. Reclam, Ditzingen.

Horstmann, R.-P. (1999): „What is Hegel's Legacy and What Should We Do With It?" European Journal of Philosophy 7 (2): 275-287.

Horstmann, R.-P. (2006): „Substance, Subject and Infinity. A Case Study for the Role of Logic in Hegel's System." In Hegel: New Directions, ed. K. Deligiorgi, Acumen Publishing, Durham s. 69-84.

Lichtenberg, G. Ch. (2004): Myšlenky, postřehy, nápady. Jitro, Praha. Matějčková, T. (2011): „Jan Kuneš - Martin Vrabec (vyd.). Místo fenomenologie ducha v současném myšlení.“ Reflexe (40): 123130.

Matějčková, T. (2020a): Hegelova fenomenologie světa. Filosofický ústav AV ČR, OIKOYMENH, Praha.

Matějčková, T. (2020b): „Précis knihy Hegelova fenomenologie světa.“ Filosofie dnes 12 (1): 3-19. Dostupné z: www.filosofiednes.ff.uhk. cz.

Nagel, T. (1974): „What Is It Like to Be a Bat?“ The Philosophical Review 83 (4): 435-450. 


\begin{abstract}
What Is It Like to Enter the World?

The proposed paper is an extensive review of the book Hegel's phenomenology of world written by Tereza Matějčková. I emphasise the key role of the concept of education (Bildund) in her interpretation. Yet, education is here not understood as an accumulation of knowing, but rather as getting rid of knowing that no longer corresponds to actuality. In my reading, through repetitive "liberating" or "emptying" itself from its old knowing, the consciousness paves the road to the world, it enters into the "new" world, leaving the old "world-order" behind in memory. Complementarily, it educates itself to live in the present moment. According to Matějčková, Hegel's Phenomneology of Spirit educates the consciousness (but also its reader) to live up to the world, its actuality and its (everyday) present. Yet, in order to fulfil this aim of Hegel's Phenomenology - and this is also my main reservation and simultaneously perhaps a stimulus for a further enquiry her interpreter should take into account the history of the twentieth century and demonstrate on it what the spirit has learned from it. Thereby, the spirit turns this history into its own history. Otherwise, the reader will continue to frame the present by the concepts of the past (tradition) and will not be truly modern.
\end{abstract}

Key words: the education, the present, the world, the labour, the post-metaphysical reading of Hegel, Matějčková

Korda, T. (2020): „Jaké to je vstupovat do světa?“ Filosofie dnes 12 (1): 93-107. Dostupné z www.filosofiednes.ff.uhk.cz 